\title{
Evolution of grapevine surfaces in Romania after accession to European Union - period 2007-2016
}

\author{
Arina Oana Antoce ${ }^{1, \mathrm{a}, \mathrm{b}}$ and Laura Lidia Calugaru ${ }^{2}$ \\ ${ }^{1}$ University of Agronomic Sciences and Veterinary Medicine of Bucharest, Faculty of Horticulture, Department of Bioengineering of \\ Horti-Viticultural Systems, 59 Marasti Ave., Sector 1, 011464 Bucharest, Romania \\ ${ }^{2}$ Romanian National Office of Vine and Wine Products (ONVPV), 49 Şos. Iancului, Sector 2, 021719 Bucharest, Romania, \\ office@onvpv.ro
}

\begin{abstract}
The paper focuses on the evolution of the surfaces planted in Romania with the main wine grape varieties and also attempts to describe the impact of the funds received for the vine and wine sector after the country's accession to European Union in 2007. The evolution of planted surfaces and production is followed for the period 2007-2016, based on the data recorded in the digital database called National Register for Vine Plantations. The study presents the evolution of the surfaces covered with the most widely spread autochthonous and international varieties, for both white and red wines, which are, in decreasing order, Fetească regală, Fetească albă, Merlot, Riesling, Aligote, Sauvignon blanc, Cabernet Sauvignon, Muscat Ottonel, Fetească neagră, Pinot noir and Chardonnay. The largest newly planted surfaces were recorded in 2011 for most of these varieties, but a high impact of the support received from the EU was visible throughout the period 2008-2012. Later on, from 2013-2016, the rate of planting started to decrease.
\end{abstract}

\section{Introduction}

The vine and wine sector is one of the most developed sectors in Romanian agriculture, which largely benefited from the country accession to European Union in 2007. The National Support Programme of Romania for 2009-2013 reported full absorption of the funds allocated for viticulture, with important investments in new plantations and in some new technologies.

The programme is followed by another similar one, planned for 2014-2018, which is ongoing at present.The funds allocation was made on the basis of the European legislation dealing with the common organisation of agricultural markets - (EC) No 1234/2007 and (EU) No $1308 / 2013$ [1,2] and common organization of the market in wine - (EC) No 1493/1999 and (EC) No 479/2008 [3,4] and the respective implementing regulations [5-7]. For example, in the period 2009-2013 the investments in the vine and wine sector in Romania were included among the measures for the rural development and not under special measures dedicated only to viti-vinicultural sector. For the new period of 2014-2018, however, Romania included such investments under the specific measures for vine and wine sector.

The allocation took into account the priorities of the country, concentrating mostly to the restructuring and conversion of vineyards and planting wine grape varieties meant for the production of quality wines with Controlled Denomination of Origin or at least with Geographical Indication. The present study is an attempt to evaluate from several viewpoints the impact of the European funds

\footnotetext{
a e-mail: arina.antoce@horticultura-bucuresti.ro

b e-mail: aantoce@yahoo.com
}

allocated to Romania with regard to the development of the vine and wine sector during the period 2007-2016. The main points of the paper refer to the evolution of the surfaces planted with the main wine grape varieties cultivated in Romania from 2005 to 2016, evolution of vine surfaces in accordance with the destination of production in each wine region and the new plantations established by using existent planting rights or allocated from the national reserve.

\section{Materials and methods}

Data were obtained from several sources, such as Statistical yearbooks of Romania issued by National Institute of Statistics [8], Ministry of Agriculture and Rural Development of Romania [9], Romanian Payment and Intervention Agency for Agriculture (APIA) [10], but mostly from reports of the Romanian National Office of Vine and Wine Products (ONVPV) [11] and Romanian National Organisation of Vine and Wine (ONVV) [12] submitted to the European Commission or to OIV. An example of such a report, which is not available for public, is "Agriculture and Rural Development ISAMM CM" sent by ONVV to the European Commission in March 2015 regarding the inventory and measurement of the area planted and also the transitional planting rights regime.

Due to the complexity of the field, both European regulations and Romanian legislation for the wine and vine sector [11] were consulted. Some regulations referred only to wine market common organisation, while others referred generally to the common organisation of agricultural markets, thus, the measures for vine and wine were based on specific provisions of either one or the other type of regulation. Basically, in accordance to 


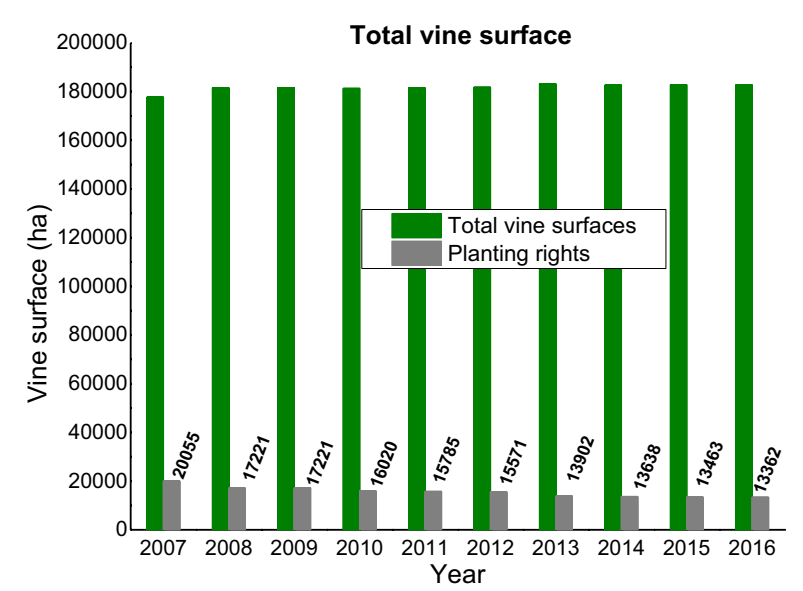

Figure 1. Vine surfaces evolution in Romania after accession to EU to present time.

(EC) No 1234/2007, the regulations regarding common organisation of agricultural markets did not cover those parts of the CMOs which were subject to policy reforms, certain elements for wine being part of these reforms. The data regarding grape varieties and planted surfaces were extracted from the Registry of the Vineyard Plantations, a national IT system developed based on an Oracle database, in which the declarations of producers are introduced since 2003. Until 2009 corrections and updates of the registry were allowed, in accordance with the documents from the vineyards owners. A functional registry of the vine plantations was a prerequisite for accession of Romania to EU. At present it is the main evaluation and control tool for the viti-viniculture sector. A new enhanced software application for the Registry was launched this year, comprising the recording of compulsory declarations (harvest, yield, stock) as mentioned in EU legislation $[4,13]$, along with required information for market research.

Based on the data from the Registry of the Vineyard Plantations the surface evolution of autochthonous and international varieties from 2007 to 2016 was examined in order to evaluate how did the National Support Plan helped Romania achieve its objectives assumed as a Member State, in the field of wine and vine.

The main grape varieties monitored and included in the reports for the European Commission are: Fetească albă, Fetească regală, Merlot, Riesling, Aligote, Sauvignon blanc, Cabernet Sauvignon, Muscat Ottonel, Fetească neagră, Pinot noir, Chardonay.

\section{Results and discussion}

\subsection{The evolution of the Romanian vine and wine sector in the period of 2007-2016}

The total vine surface in Romania, as presented in Fig. 1, has not fluctuated much since 2007, only a very slight increase being recorded in recent years due to the new plantings.

The total surface covered with vine in Romania reported in 2015 was 182,849 ha, of which 96,492 ha Vitis vinifera vine varieties and 86,357 ha of interspecific hybrids (hybrid vine varieties temporarily accepted in culture).

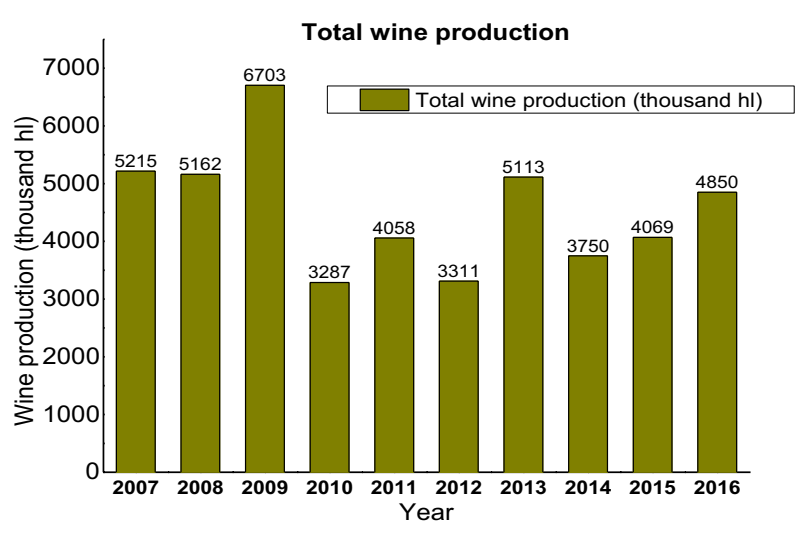

Figure 2. Wine production evolution in Romania from UE accession to present time.

To this surface 13,463 ha are added as planting rights in various stages of usage (planting rights allocated to producers but not yet used - 1,739 ha, replanting rights currently held by the producers - 9,536 ha and planting rights still existing in the reserve $-2,188$ ha), leading to a total viticultural potential of 196,312 ha (ISAMM-CM 2015).

The values of 2016 (not yet officially reported at the moment of paper writing) are not very much different from those of 2015, the total vine surface being 182,763 ha to which planting rights are added in surface of 13,362 ha.

The planting rights reserve allocated to Romania upon accession to EU (in amount of 2,830.5 ha) are included in the present national reserve.

Basically, between 2007 and 2016 the total vine surface remained relatively constant, even though the influx of EU funds made a clear difference in the varieties planted and vine renewal. From 2007 the planting rights from the national reserve decreased slowly, with a more important decrease in 2013, when due to the infusion of the EU funds more vine was planted. In Romania the vine planting is only permitted if a planting right is used, either a new planting right, or a replanting right or a right allocated from the national reserve. This is set in Art. 63 of Regulation (UE) nr. 1308/2013 [2] which repeals previous regulations forbidding the planting of grapevine until December $31^{\text {st }}$, 2015.

The destinations of the vine surfaces for the wine production were in 2015 (ISAMM-CM 2015) as follows:

31,532 ha (17.25\%) - surfaces for wine with protected denomination of origin (DOC)

- 18,600 ha (10.17\%) - surfaces for wine with protected geographic indication (IG)

- 132,717 ha $(72.58 \%)$ - surfaces for wine without protected DOC/IG.

The wine produced and meant for commerce is only based on the Vitis vinifera varieties; thus, when considered in view of the total surfaces covered with vine, the Romanian wine production is lower than expected. The evolution of the wine produced and commercialized in Romania from 2007 to 2016 is presented in Fig. 2, with the resulted categories of wines included in Fig. 3.

We can see that in the period 2010-2013 the wine production decreased, but this is explained by the fact that in this period old vineyards were grubbed and new 


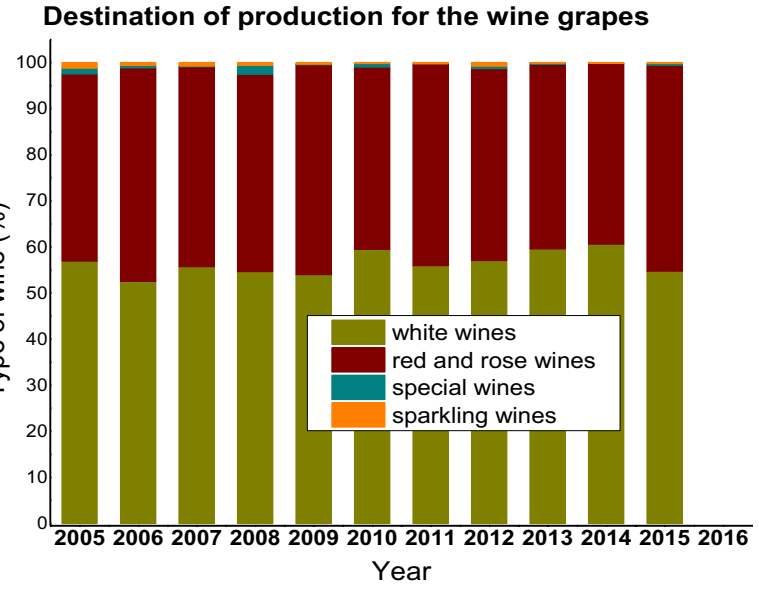

Figure 3. Destination of the wine grape production in Romania from 2005 to 2015 .

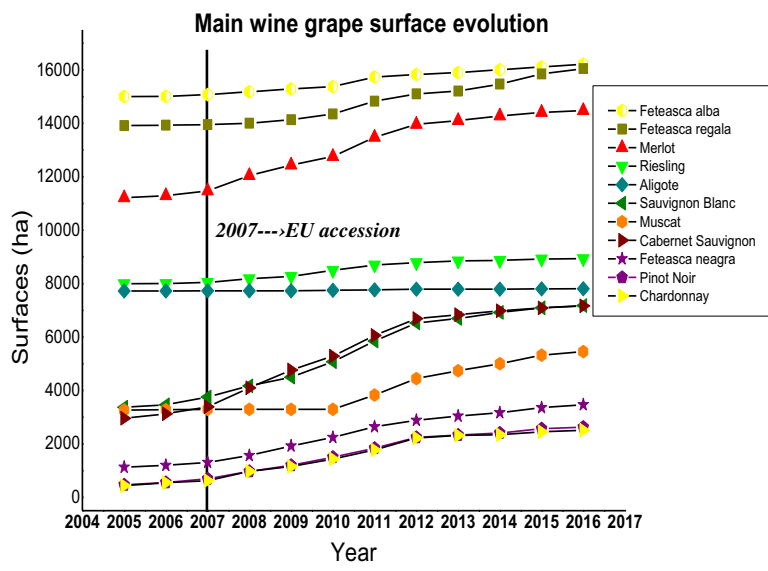

Figure 4. Evolution of surfaces cultivated with the main wine grape varieties in Romania from 2005 to 2016.

vineyards, which need time to enter production, were planted with European funds.

\subsection{Evolution of wine grape varieties from 2005 to 2016}

More than 140 Vitis vinifera and interspecific grape varieties are cultivated in Romania, but not all cover important surfaces. Out of these only about 40 wine grape varieties are found on surfaces larger than 100 ha. The most important varieties cultivated in Romania on significant surfaces are included in Table 1 and their evolution in time is plotted in Fig. 4.

Starting with 2007, the year of Romania's accession to EU, all these main varieties had their surfaces increased. With the exception of Riesling and Aligote, which registered only slight surface increases during the entire reported period, all the other main varieties recorded clear growth, with a sharp increase between 2008 and 2012, when the European funds were absorbed the most efficiently (Fig. 4).

Due to the infusion of European funds, the relative distribution of the main varieties in 2016 differs compared with 2007 (Fig. 5), with a relative increase of the international varieties Cabernet Sauvignon, Chardonnay, Sauvignon blanc, Pinot noir and Muscat, but also with an increase for the indigenous Feteasca neagra. While
Main wine grape varieties in 2007

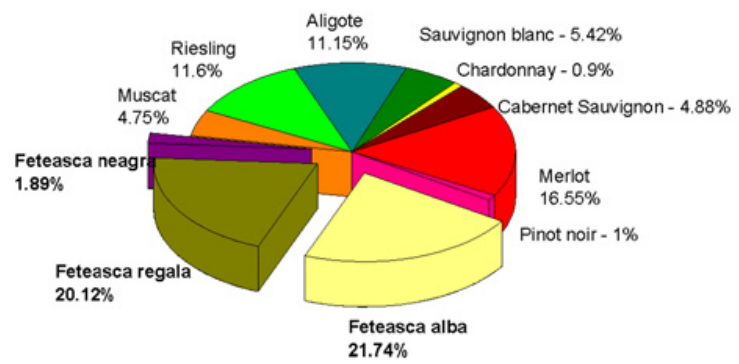

Main wine grape varieties in 2016

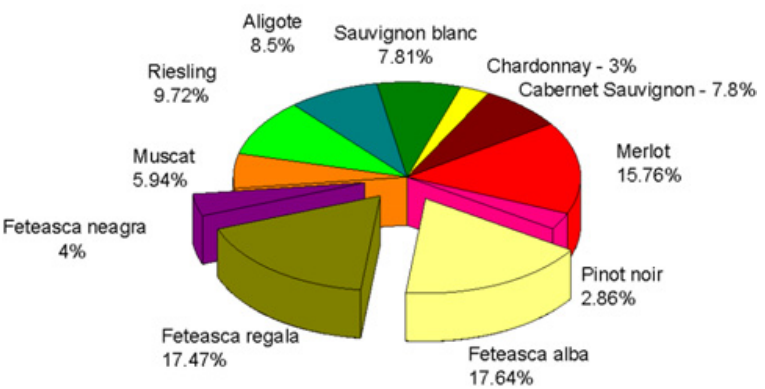

Figure 5. Relative distribution of the main wine grape varieties in Romania at the accession to EU (2007) and at present (2016). The percentages are calculated as reported to the total surface of these varieties.

still being the most widespread varieties in Romania, the white autochthonous varieties Feteasca alba and Feteasca regala recorded a relative decrease. Also a reduction was observed for surfaces with Riesling, Aligote and Merlot.

\subsection{Evolution of vine surfaces in accordance to the wine regions and destination of production}

In accordance to the geographic position and some other particularities of climate and soil, in Romania are defined eight wine regions. More information about Romanian wine regions, varieties and wines can be found in our previous publications $[14,15]$.

As mentioned before, the vine surfaces are distributed in the most favourable regions of the country, the largest wine regions being the 1-Hills of Moldova followed by the 2-Hills of Vallachia and Oltenia (Fig. 6).

The new investments in vineyard took into account the necessary increase in wine quality, thus, the new plantations were mostly destined for the DOC wine production. As a consequence, in all the regions were DOC wines are approved, the DOC surfaces increased in 2016 as compared to 2007 , by 1.1 to 5.5 times, in accordance to the wine region (Table 2).

Thus, it can be seen that after EU accession the surfaces meant for DOC wine production significantly increased in all wine regions, with the exception of the region of Danube Terraces, where there is no denomination of origin approved.

However, the overall quantities of red wines obtained did not increase as much as expected (Table 3), the percentage of red wines remaining in the range of $40-45 \%$ (Fig. 7), even though the total wine production fluctuated largely in accordance to each year's climatic conditions. 
Table 1. Evolution of the main wine grape varieties cultivated in Romania from 2005 to 2016 (from ONVPV).

\begin{tabular}{|l|l|l|l|l|l|l|l|l|l|l|l|l|}
\hline \multirow{2}{*}{ Grape variety } & \multicolumn{10}{|c|}{ Vine surface (ha) } \\
\cline { 2 - 12 } & $\mathbf{2 0 0 5}$ & $\mathbf{2 0 0 6}$ & $\mathbf{2 0 0 7}$ & $\mathbf{2 0 0 8}$ & $\mathbf{2 0 0 9}$ & $\mathbf{2 0 1 0}$ & $\mathbf{2 0 1 1}$ & $\mathbf{2 0 1 2}$ & $\mathbf{2 0 1 3}$ & $\mathbf{2 0 1 4}$ & $\mathbf{2 0 1 5}$ & $\mathbf{2 0 1 6}$ \\
\hline Feteasca alba & 15004 & 15007 & 15075 & 15180 & 15287 & 15375 & 15733 & 15828 & 15901 & 16005 & 16111 & 16210 \\
Feteasca regala & 13915 & 13934 & 13950 & 14005 & 14134 & 14353 & 14828 & 15104 & 15206 & 15469 & 15850 & 16052 \\
Merlot & 11216 & 11294 & 11472 & 12044 & 12440 & 12758 & 13480 & 13964 & 14106 & 14278 & 14411 & 14480 \\
Riesling & 7997 & 8001 & 8045 & 8180 & 8271 & 8497 & 8698 & 8787 & 8848 & 8872 & 8922 & 8936 \\
Aligote & 7727 & 7727 & 7728 & 7728 & 7728 & 7753 & 7769 & 7793 & 7793 & 7794 & 7805 & 7811 \\
Sauvignon blanc & 3375 & 3465 & 3757 & 4170 & 4499 & 5078 & 5851 & 6528 & 6696 & 6919 & 7096 & 7176 \\
Cabernet Sauvignon & 2956 & 3125 & 3387 & 4100 & 4768 & 5287 & 6060 & 6692 & 6837 & 6985 & 7087 & 7170 \\
Muscat & 3267 & 3278 & 3293 & 3296 & 3296 & 3296 & 3830 & 4447 & 4741 & 5000 & 5323 & 5457 \\
Feteasca neagra & 1130 & 1195 & 1307 & 1568 & 1924 & 2245 & 2643 & 2885 & 3043 & 3170 & 3360 & 3467 \\
Pinot noir & 466 & 554 & 695 & 970 & 1196 & 1501 & 1841 & 2241 & 2333 & 2407 & 2567 & 2627 \\
Chardonnay & 434 & 544 & 626 & 970 & 1158 & 1432 & 1777 & 2223 & 2317 & 2344 & 2454 & 2511 \\
\hline
\end{tabular}

Table 2. The surface with vineyards distributed in accordance to the Romanian wine regions in 2007 (time of EU accession) and in 2016 (from ONVPV Communication 2007 and Vine Plantations Registry, ONVPV, 2015-2016).

\begin{tabular}{|c|c|c|c|c|c|c|c|c|c|}
\hline \multirow[t]{2}{*}{ Wine region } & \multirow{2}{*}{$\begin{array}{l}\text { Total } \\
\text { surface (ha) } \\
\text { in } 2007 \\
\text { (EU accession) }\end{array}$} & \multirow{2}{*}{$\begin{array}{l}\text { DOC } \\
\text { surface } \\
\text { in } 2007 \\
\text { (ha) }\end{array}$} & \multirow{2}{*}{$\begin{array}{l}\text { Surfaces with } \\
\text { IG and } \\
\text { without } \\
\text { DOC/IG in } \\
2007 \text { (ha) }\end{array}$} & \multirow{2}{*}{$\begin{array}{l}\text { Total } \\
\text { surface } \\
\text { (ha) } \\
\text { in } 2016\end{array}$} & \multirow{2}{*}{\begin{tabular}{|l}
$D O C$ \\
surface \\
in 2016 \\
(ha)
\end{tabular}} & \multirow{2}{*}{$\begin{array}{l}\text { IG surface } \\
\text { in } 2016 \\
(\text { ha })\end{array}$} & \multirow{2}{*}{$\begin{array}{l}\text { Surfaces } \\
\text { without } \\
\text { DOC/IG } \\
\text { in } 2016 \\
\text { (ha) }\end{array}$} & \multicolumn{2}{|c|}{$\begin{array}{c}\text { DOC surface increase } \\
\text { in } 2016 \text { as compared } \\
\text { to } 2007\end{array}$} \\
\hline & & & & & & & & times & $\%$ \\
\hline 1. Transylvanian plateau & 6604.84 & 1432.57 & 5172.27 & 6953.13 & 3919.99 & 80.62 & 2952.52 & 2.74 & 173.63 \\
\hline 2. Hills of Moldova & 70504.87 & 7419.38 & 63085.49 & 69156.73 & 8267.69 & 11901.23 & 48987.81 & 1.11 & 11.43 \\
\hline $\begin{array}{l}\text { 3. Hills of Vallachia and } \\
\text { Oltenia }\end{array}$ & 49492.97 & 3911.92 & 45581.05 & 52829.18 & 8300.78 & 1596.43 & 42931.97 & 2.12 & 112.19 \\
\hline 4. Hills of Banat & 2722.83 & 838.07 & 1884.76 & 2962.43 & 1774.72 & 22.94 & 1164.77 & 2.12 & 111.76 \\
\hline $\begin{array}{l}\text { 5. Hills of Crisana and } \\
\text { Maramures }\end{array}$ & 7942.99 & 356.82 & 7586.17 & 9614.48 & 1957.98 & 710.55 & 6945.95 & 5.49 & 448.73 \\
\hline 6. Hills of Dobrogea & 15748.56 & 6924.77 & 8823.79 & 17008.88 & 8333.3 & 3239.57 & 5436.01 & 1.20 & 20.340 \\
\hline 7. Danube Terraces & 11822.0 & 0 & 11822.0 & 11250.6 & 0 & 417.57 & 10833.03 & 0 & 0 \\
\hline $\begin{array}{l}\text { 8. Sands and other } \\
\text { Favourable Lands of the } \\
\text { south of the country }\end{array}$ & 13261.68 & 0 & 13261.68 & 12941.35 & 245.82 & 296.23 & 12399.3 & N/A & N/A \\
\hline Total: & 178100.74 & 20883.53 & 157217.21 & 182716.78 & 32800.28 & 18265.14 & 131651.36 & 1.57 & 57.06 \\
\hline
\end{tabular}

Table 3. Amounts and types of wine produced in each year.

\begin{tabular}{|l|l|l|l|l|l|l|l|l|l|l|l|}
\hline \multirow{2}{*}{ Type of wine } & \multicolumn{10}{|c|}{ Wine quantity $(1000 \mathrm{hl})$} \\
\cline { 2 - 13 } & $\mathbf{2 0 0 5}$ & $\mathbf{2 0 0 6}$ & $\mathbf{2 0 0 7}$ & $\mathbf{2 0 0 8}$ & $\mathbf{2 0 0 9}$ & $\mathbf{2 0 1 0}$ & $\mathbf{2 0 1 1}$ & $\mathbf{2 0 1 2}$ & $\mathbf{2 0 1 3}$ & $\mathbf{2 0 1 4}$ & $\mathbf{2 0 1 5}$ \\
\hline White & 1518.7 & 2860.7 & 2768.0 & 289.0 & 3637.0 & 1976.3 & 2276.7 & 1913.8 & 2976.1 & 2275.6 & 1998.1 \\
Red & 1083.5 & 2521.0 & 2153.0 & 2264.8 & 3066.0 & 1311.0 & 1781.5 & 1396.8 & & 1474.2 & 1629.5 \\
Special & 32.3 & 28.1 & 7.3 & 103.0 & 0.0 & 26.06 & 0.30 & 17.0 & 12.1 & 0.1 & 14.7 \\
Sparkling & 32.0 & 33.3 & 36.0 & 30.1 & 23.1 & 5.4 & 9.9 & 25.9 & 4.6 & 4.9 & 6.1 \\
\hline Total & 2666.5 & 5443.1 & 4964.3 & 2686.9 & 6726.1 & 3318.7 & 4068.4 & 3353.5 & 2992.8 & 3754.9 & 3648.3 \\
\hline
\end{tabular}

\subsection{Evolution of investments and new plantations after the EU Accession}

The infusion of funds after the EU accession greatly benefited the Romanian vine and wine sector.

In viticulture, most funds were allocated for restructuring and conversion of the vine plantations, as seen in Table 4. A total of 288.7 million Euro were invested in the wine and vine sector between 2007-2014, around 98\% going each year into the replacement of old plantations.

The new plantations were approved and financed only with compliance with the grape varieties zoning regulations of Romania (Ministry Order 225 of 2006), as a prerequisite of quality wine production in each specific wine region.

The new surfaces planted with wine grapes are shown in Figs. 8-11, grouped in surfaces covered with the main white and black varieties, autochthonous and international, respectively.

Also, in Fig. 12 the total new vine plantations are reported, from 2005 to 2016.

Until 2013 the funds allocated to the wine and vine sector were absorbed entirely. The maximum impact of the European funds allocated to Romania after 2007 was seen in the year 2011 (Fig. 12), when the plantings with the white and black international varieties were given priority, 
Table 4. Funds allocated in Romanian viticulture between 2007 and 2016 (Romanian Payment and Intervention Agency for Agriculture, 2017).

\begin{tabular}{|c|c|c|c|c|c|c|c|c|c|}
\hline \multirow[t]{2}{*}{ Vintage year } & \multicolumn{2}{|c|}{$\begin{array}{l}\text { Vineyards restructuring } \\
\text { conversion }\end{array}$} & \multirow{2}{*}{$\begin{array}{c}\begin{array}{c}\text { Harvest } \\
\text { insurance } \\
\text { must }\end{array} \\
\text { euro }\end{array}$} & \multirow{2}{*}{\begin{tabular}{|c|}
$\begin{array}{c}\text { Use of } \\
\text { concentrated } \\
\text { (rectified) } \\
\text { markets }\end{array}$ \\
euro \\
\end{tabular}} & \multirow{2}{*}{ 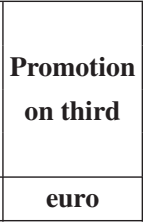 } & \multirow{2}{*}{\begin{tabular}{|c|}
$\begin{array}{c}\text { Investments } \\
\text { from EU }\end{array}$ \\
euro
\end{tabular}} & \multirow{2}{*}{\begin{tabular}{|c|} 
Total allocated \\
euro
\end{tabular}} & \multicolumn{2}{|c|}{ TOTAL used } \\
\hline & euro & $\%$ of allocation & & & & & & euro & $\%$ \\
\hline $2006 / 2007$ & $6,893,687.59$ & 81.1 & - & - & - & - & $8,500,000.00$ & $6,893,687.59$ & 81.1 \\
\hline $2007 / 2008$ & $35,050,227.75$ & 100.1 & - & - & - & - & $35,000,000.00$ & $35,050,227.75$ & 100.1 \\
\hline $2008 / 2009$ & $41,692,714.49$ & 99.0 & $323,423.24$ & $29,494.27$ & 54.40 & - & $42,100,000.00$ & $42,045,686.40$ & 99.9 \\
\hline $2009 / 2010$ & $41,548,576.08$ & 98.7 & $360,658.94$ & $81,283.31$ & 109.48 & - & $42,100,000.00$ & $41,990,627.81$ & 99.7 \\
\hline $2010 / 2011$ & $41,182,059.13$ & 97.8 & $269,524.10$ & $76,458.11$ & 571.96 & - & $42,100,000.00$ & $41,528,613.30$ & 98.6 \\
\hline $2011 / 2012$ & $40,990,098.37$ & 97.4 & $306,211.10$ & $56,044.92$ & 747.64 & - & $42,100,000.00$ & $41,353,102.03$ & 98.2 \\
\hline $2012 / 2013$ & $41,183,602.36$ & 97.8 & $230,808.69$ & - & 663.12 & - & $42,100,000.00$ & $41,415,074.17$ & 98.4 \\
\hline $2013 / 2014$ & $47,084,204.96$ & 98.7 & $253,321.27$ & - & 362.47 & - & $47,700,000.00$ & $47,337,888.70$ & 99.2 \\
\hline $2014 / 2015$ & $18,995,454.62$ & 39.8 & $228,617.54$ & - & 699.41 & - & $47,700,000.00$ & $19,224,771.57$ & 40.3 \\
\hline $2015 / 2016$ & $10,940,798.41$ & 22.9 & $186,734.05$ & - & 479.33 & $70,473.87$ & $47,700,000.00$ & $11,198,485.66$ & 23.5 \\
\hline TOTAL 2007-2016 & $325,561,423.76$ & 82.0 & $2,159,298.93$ & $243,280.61$ & $3,687.81$ & 70,473.87 & \begin{tabular}{|l|}
$397,100,000.00$ \\
\end{tabular} & $328,038,164.98$ & 82.6 \\
\hline & $99.24 \%$ & & $0.66 \%$ & $0.07 \%$ & $0.00 \%$ & $0.02 \%$ & & $100 \%$ & \\
\hline
\end{tabular}

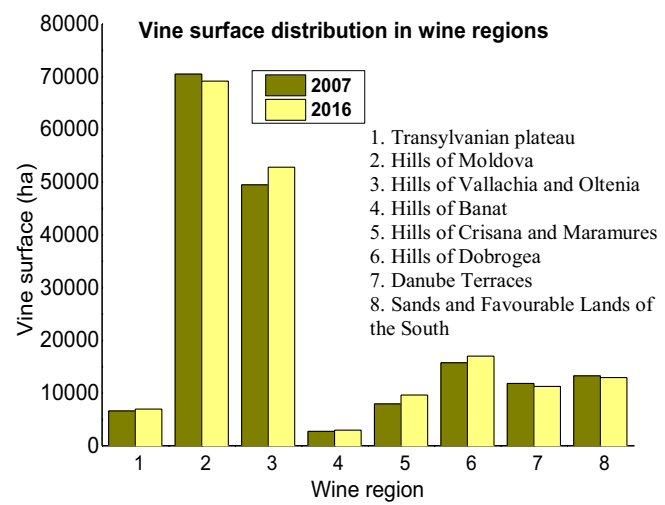

Figure 6. The vine surface distribution in wine regions at EU accession (2007) and at present (2016).

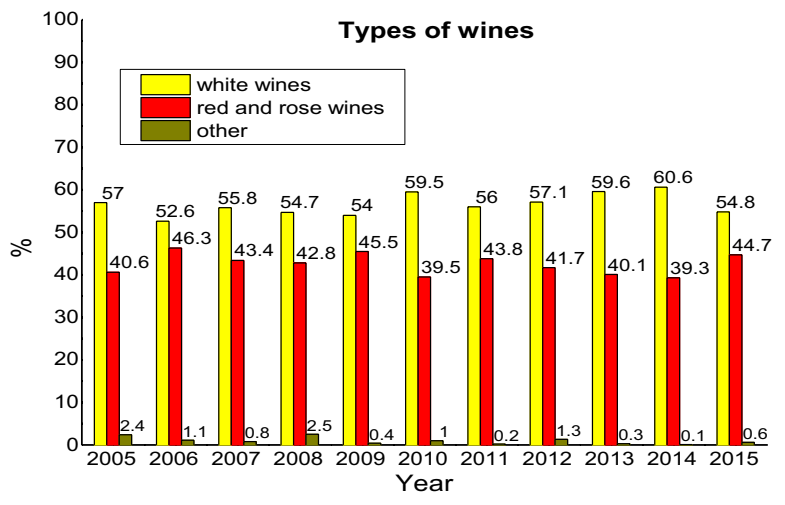

Figure 7. The wine assortment in accordance to the main types: white, red/rosé and other.

Sauvignon Blanc (Fig. 9), Cabernet Sauvignon and Merlot (Fig. 11) being also at the top of the producers' list.

The black autochthonous variety Fetească Neagră also had a significant evolution, being one of the most preferred varieties for the new plantings (Fig. 10).

The autochthonous white varieties, Feteasca alba and Feteasca regala were not neglected either (Fig. 8).

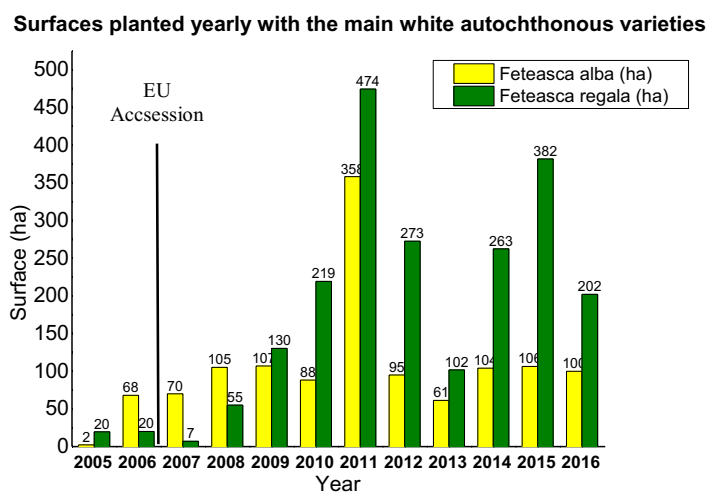

Figure 8. The surfaces planted yearly with the main white autochthonous varieties - period 2005-2016.

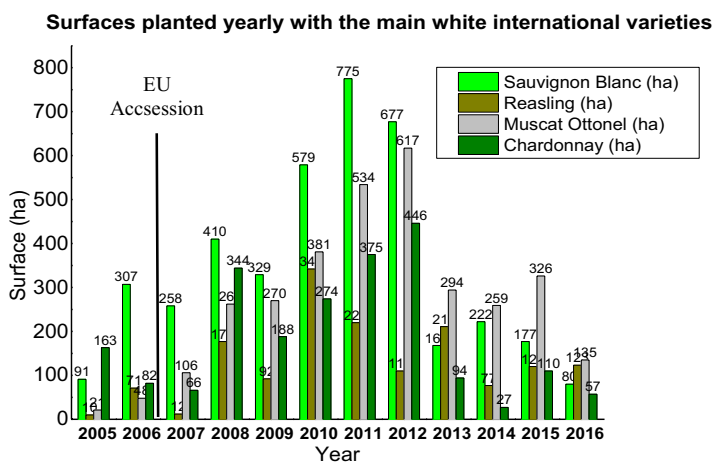

Figure 9. The surfaces planted yearly with the main white international varieties - period 2005-2016.

Starting with 2013 a sharp decrease is seen in the investments in new vine plantations, due mainly to some legislative measures which led to a temporary blockage. Thus, for the year 2016, out of the available 47.7 million Euro only 12 million were absorbed, the new plantings reaching only 895 ha.

There are reasons to believe that Romania will continue the success story in its viticulture domain, 


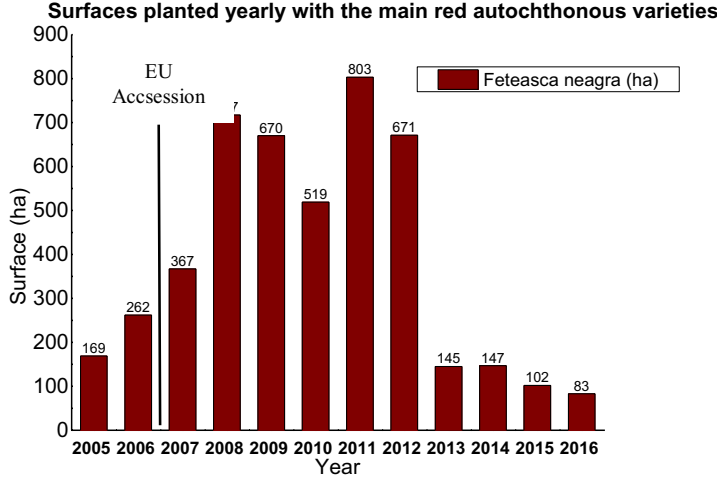

Figure 10. The surfaces planted yearly with the main black autochthonous varieties - period 2005-2016.

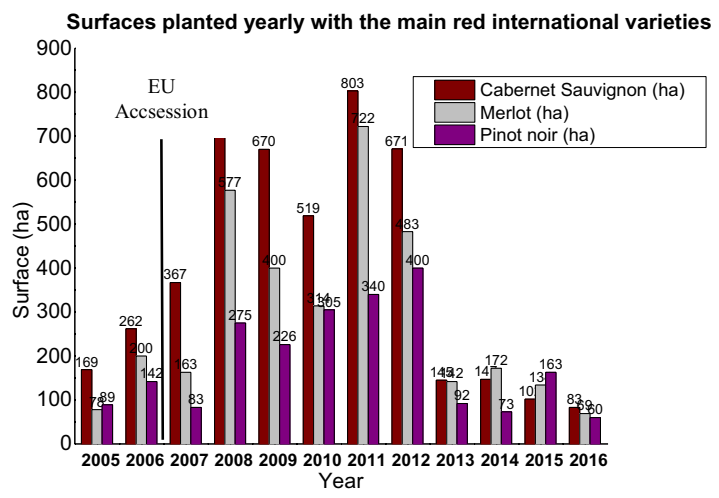

Figure 11. The surfaces planted yearly with the main black international varieties - period 2005-2016.

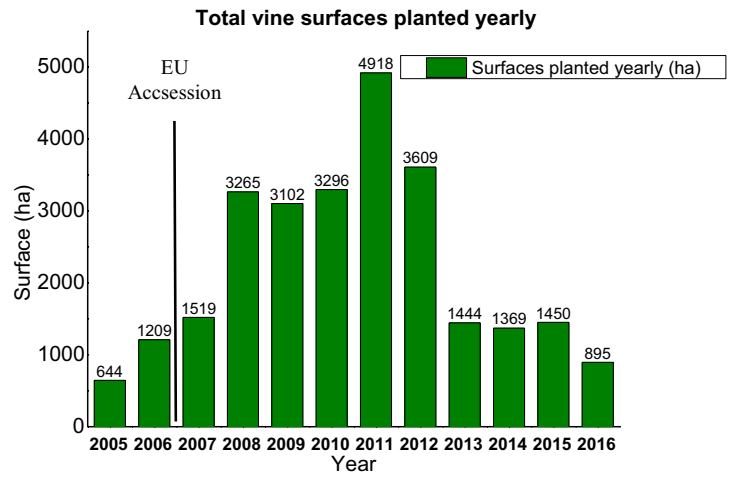

Figure 12. The total vine surfaces planted yearly - period 2005-2016.

with the new National Viticultural Programme 20142018, for which 238.5 million Euro are allocated, that is 47.7 million Euro per year.

\section{Conclusions}

The Romanian vitiviniculture was one of the areas of the economy which greatly benefited from the accession to EU. The most important changes were seen in the renewal of the vine plantations, as almost $90 \%$ of the funds allocated through the National Support Plan 2009-2013 for viticulture were spent in restructuring and conversion. During this period the investments in equipment for viticulture and winemaking were actually not covered in the viticulture programme, but in the rural and development programmes for agriculture, thus, only few such investments were made due to high competition from other agricultural sectors. Even so, the entire funds distributed to Romania were very useful, several years in a row during this first programme the funds allocated in viticulture being totally absorbed. The second programme, for 2014-2018, is ongoing, with some changes regarding the objectives, including the investments in equipment. The absorption slowed down, however, due to some legislation inconsistencies and delays in application. The restructuring and conversion helped renew the existing plantations, which were not anymore adapted to market demand - but also helped with the establishing of new plantations, based on using individual planting rights or from the national reserve, so that the total surface of vineyard existent in the country could be kept at the level negotiated at the time of the accession to EU. Grapevine varieties currently in low demand were replaced with valuable autochthonous varieties or international varieties. An increase was observed for the autochthonous Feteasca Neagră, as well as for the international varieties such as Cabernet Sauvignon, Chardonnay and Sauvignon Blanc.

\section{References}

[1] COUNCIL REGULATION (EC) No $1234 / 2007$ of 22 October 2007 establishing a common organisation of agricultural markets and on specific provisions for certain agricultural products (Single CMO Regulation) (http: //eur-lex.europa.eu/legal-content/ en/TXT/?uri=CELEX : 32007R1234)

[2] REGULATION (EU) No 1308/2013 OF THE EUROPEAN PARLIAMENT AND OF THE COUNCIL of 17 December 2013, establishing a common organisation of the markets in agricultural products and repealing Council Regulations (EEC) No 922/72, (EEC) No 234/79, (EC) No 1037/2001 and (EC) No 1234/2007. (http: //eur-lex.europa.eu/legal-content/ EN/TXT/?qid=1491852068735\&uri=CELEX : 32013R1308)

[3] COUNCIL REGULATION (EC) No 1493/1999 of 17 May 1999 on the common organisation of the market in wine (http: //eur-lex.europa.eu/ legal-content/EN/TXT/?qid=1491852068735\& uri=CELEX : 31999R1493)

[4] COUNCIL REGULATION (EC) No 479/2008 of 29 April 2008 on the common organisation of the market in wine, amending Regulations (EC) No 1493/1999, (EC) No 1782/2003, (EC) No 1290/2005, (EC) No 3/2008 and repealing Regulations (EEC) No 2392/86 and (EC) No 1493/1999 (http: //eur-lex.europa.eu/legal-content/ EN/TXT/?qid=1491852068735\&uri=CELEX : 32008R0479)

[5] Commission Delegated Regulation (EU) 2015/560 of 15 December 2014 supplementing Regulation (EU) No 1308/2013 of the European Parliament and of the Council as regards the scheme of authorisations for vine plantings (http://eur-lex.europa.eu/legal-content/ EN/TXT/?qid=1491855210950\&uri=CELEX : 32015R0560) 
[6] Commission Implementing Regulation (EU) 2015/561 of 7 April 2015 laying down rules for the application of Regulation (EU) No 1308/2013 of the European Parliament and of the Council as regards the scheme of authorisations for vine plantings (http://eur-lex.europa.eu/legalcontent/EN/TXT/?qid=1491852414527\&uri= CELEX : 32015R0561)

[7] Commission Implementing Regulation (EU) $2015 / 1991$ of 5 November 2015 amending Regulation (EC) No 555/2008 laying down detailed rules for implementing Council Regulation (EC) No $479 / 2008$ on the common organisation of the market in wine as regards support programmes, trade with third countries, production potential and on controls in the wine sector. (http: //eur-lex.europa.eu/ legal-content/EN/TXT/?qid=1491852414527\& uri $=$ CELEX : 32015R1991)

[8] Statistical yearbooks of Romania issued by National Institute of Statistics, Archives: http://www.insse.ro/cms/en/content/ statistical-yearbooks-romania

[9] Ministry of Agriculture and Rural Development of Romania, http://www.madr.ro/en/; http://www.madr.ro/en/horticulture/ viticulture-enology.html
[10] Romanian Payment and Intervention Agency for Agriculture (APIA), http://www . apia.org.ro/

[11] Romanian National Office of Vine and Wine Products (ONVPV), http://www.onvpv.ro/; http://www .onvpv.ro/ro/content/legislatie

[12] Romanian National Organisation of Vine and Wine (ONVV), http: //www. onvv.ro/

[13] Commission Regulation (EC) No 436/2009 of 26 May 2009 laying down detailed rules for the application of Council Regulation (EC) No $479 / 2008$ as regards the vineyard register, compulsory declarations and the gathering of information to monitor the wine market, the documents accompanying consignments of wine products and the wine sector registers to be kept. http://eur-lex.europa.eu/legal-content/ en/TXT/?uri=CELEX : 32009R0436

[14] Antoce A. O., Nămoloşanu I., Duşa D., Mereanu D., Rebigan C., Nicolau V., Călugăru L., Some considerations regarding the grapevine variety assortment and wine categories in Romania in recent years", Bulletin de l'OIV, 86, ian-feb-mar 2013, No. 983-984-985, pp 27-45 (2013).

[15] Nămoloşanu I. and Antoce A. O., 2000, Romanian viticulture on the verge of the third millennium, Die Wein Wissenschaft, Vitic. Enol. Sci. 55(2), 67-72 